\title{
Quartzite pebble technology in the final Middle Pleistocene of the Ribeira da Ponte da Pedra site (High Ribatejo, Central Portugal)
}

\author{
Sara Cura ${ }^{1,2}$, Stefano Grimaldi ${ }^{2,3}$, Pedro Cura ${ }^{1}$, Pierluigi Rosina ${ }^{2,4}$ \\ 1. Earth and Memory Institute, Largo Infante D.Henrique 6120 -450, Mação, Portugal. Email: S. \\ Cura: 0saracura0@gmail.com; P. Cura: 0pedrocura@gmail.com \\ 2. Quaternary and Prehistory Group of Geosciences Center Unit (uID73 - FCT) Largo Infante D.Henrique 6120 - \\ 450, Mação, Portugal. Email: Grimaldi: stefano.grimaldi@unitn.it; Rosina: prosina@ipt.pt \\ 3. Dipartimento di Lettere e Filosofia, Universitàdegli studi di Trento, I-38122, Trento, Italy. \\ 4. Instituto Politécnico de Tomar, Portugal. 2. Quaternary and Prehistory Group of Geosciences Center Unit \\ (uID73 - FCT Quinta do Contador, Estrada da Serra, 2330-313, Tomar, Portugal.
}

\begin{abstract}
:
The lithic assemblage of Ribeira da Ponte da Pedra site (OIS8-9) was produced, almost exclusively, through the exploitation of good quality quartzite fluvial pebbles with a regular morphology. Quartzite fluvial pebbles are the most common raw material found in the Middle Pleistocene occupation sites in Portugal. Such feature results from the easy availability of these pebbles in the valleys where the great majority of the archaeological sites within this chronology are located, and also because of the quartzite's physical properties and suitability for knapping.

In a techno-typological point of view, its lithic assemblage is characterized by the application of two main reduction sequences that result in abundant worked pebbles, retouched pebbles, cortical and semi-cortical flakes, retouched flakes, a few cores and rare bifacial artefacts. Some artefacts present irregular and variable edge modifications described as 'atypical' edge modifications that could edge damage resultant from their utilization. From a strictly technical point of view the assemblage can be described as quite simple, however we can envisage an inherent complexity starting in an accurate selection and exploitation of the quartzite pebbles, whose regular morphology allows a 'predetermined' production of regular blanks through simple actions.

In order to better understand patterns of raw material selection and technical schemes adopted in the exploitation of the quartzite pebbles we compared a sample of pebbles collected in the same deposits identified in the site (t4 fluvial terrace deposits) with worked pebbles that have 1 or 2 removals that had not altered significantly the original morpho-volumetry of the pebbles. The goal of this comparison was to verify if there was a selection of the fluvial pebbles based on texture and morpho-volumetry and if so, relate such selection with the technical schemes identified by technological study of the assemblage.
\end{abstract}

Keywords: Middle Pleistocene; lithic technology; raw materials; quartzite pebbles; edge modifications; Experimental archaeology; Ribeira da Ponte da Pedra

Published by the School of History, Classics and Archaeology, University of Edinburgh ISSN: 2055-0472. URL: http://journals.ed.ac.uk/lithicstudies/

This work is licensed under a Creative Commons Attribution 2.5 UK: Scotland License. 


\section{Introduction}

Our study analyses the exploitation models of fluvial quartzite pebbles developed by the final Middle Pleistocene human groups living in Central Portugal. The focus is to define the ensemble of technical choices and economic objectives that satisfy the needs of the prehistoric human group with the understanding of the archaic human behaviour as one the main study goals (Grimaldi 1998). The key point is the lithic assemblage found in the Ribeira Ponte da Pedra open-air site (hereafter RPP), located in the deposits T4 fluvial terrace of the Low Tagus River valley in Central Portugal. In order to better understand patterns of raw material selection and technical schemes adopted in the exploitation of the quartzite pebbles we compared a sample of pebbles collected in the same deposits identified in the site (t4 fluvial terrace deposits) with worked pebbles that have 1 or 2 removals that had not altered significantly the original morpho-volumetry of the pebbles. The goal of this comparison was to verify if there was a selection of the fluvial pebbles based on texture and morphovolumetry and if so, relate such selection with the technical schemes identified by technological study of the assemblage. The results presented in this paper lead us to recognise a predetermined exploitation of the quartzite pebbles available in the surroundings of the site. Pebbles with a regular morpho-volumetry and fine to medium grained texture were preferentially selected and allowed a "predetermined" production of blanks with "simple" technical schemes.

Despite the abundance of Middle Pleistocene quartzite assemblages in Europe, there have been few advances in the understanding on what concerns the technology and functionality of this raw material (Colonge \& Mourre 2009; Cristiani 2010; Cura 2014; Cura et al. 2014; Di Modica \& Bonjean 2009; Moncel et al. 2009; Moloney et al. 1996; Sternke et al. 2009; Tuffreau et al. 2009). Additional research integrating different methods of analysis is necessary to enhance our understanding of the real impact of the use of this raw material considering its mechanical properties, morpho-volumetry, acquisition strategies, manufacturing techniques, curation, transport, use, maintenance and discard, and thus providing insights into human behaviour.

\subsection{Middle Pleistocene evidences in the Portuguese Low Tagus Valley}

Most of the Middle Pleistocene evidences known today in the Low Tagus valley in Portugal are mainly found in river terraces and occasionally in karst deposits.

In what concerns to raw materials, quartzite is the dominant raw material in Portuguese Middle Pleistocene sites (Cunha Ribeiro 1999; Meireles 1992; Meireles \& Cunha Ribeiro 1992; Oosterbeek et al. 2010) and has a considerable presence in Upper Pleistocene sites (Pereira et al. 2012). In fact the overriding presence of this raw material in the Middle Pleistocene extends to a large part of the Iberian Peninsula (Moloney et al. 1996). This situation is primarily determined by the general geological features of the area, which include vast regions devoid of calcareous formations (Santonja \& Villa 2006) where other raw materials are available. Even in regions where flint is locally available, quartzite is often the most selected raw material for the production of Acheulean large blanks, as demonstrated, for example, by several sites in the region of La Rioja in Spain (Utrila \& Mazzo 1996).

Studies at the archaeological sites located in the T4 fluvial terrace the Tagus River, near the Alpiarça village, are an example of research based on the typology of the lithic artifacts combined with geomorphologic analysis (Mozzi et al. 2000). In the Vale do Forno and Vale da Atela (Figure 1), within the two main sedimentary units of the middle terrace of the Tagus River, the Lower Gravels and the Upper Sands, several sites have been excavated and subject to detailed studies, including TL dating (Mozzi et al. 2000). The sites associated with the Upper Sands unit are more relevant, namely the sites of Vale do Forno 1, 3 and 8. The Vale 
do Forno 1 lithic artifacts consist, according to the author's, of a not very evolved Acheulean type (Middle Acheulean) (Mozzi et al. 2000). The Vale do Forno 8 excavation revealed an assemblage of around 3000 artefacts, which have not been extensively published, but are described as "an Upper Acheulian industry with many tools on flakes and bifaces with good flaking technique", (Mozzi et al. 2000: 365). Finally, the lithic assemblage from the Vale do Forno 3, also known as Milharós, is considered as Late Acheulian of Micoquian type. This cultural attribution is based on the exquisite configuration and other typological features of some lanceloate and micoquian bifaces (Mozzi et al. 2000: 365; Raposo 2002; Raposo et al. 1985; Raposo et al. 1993).

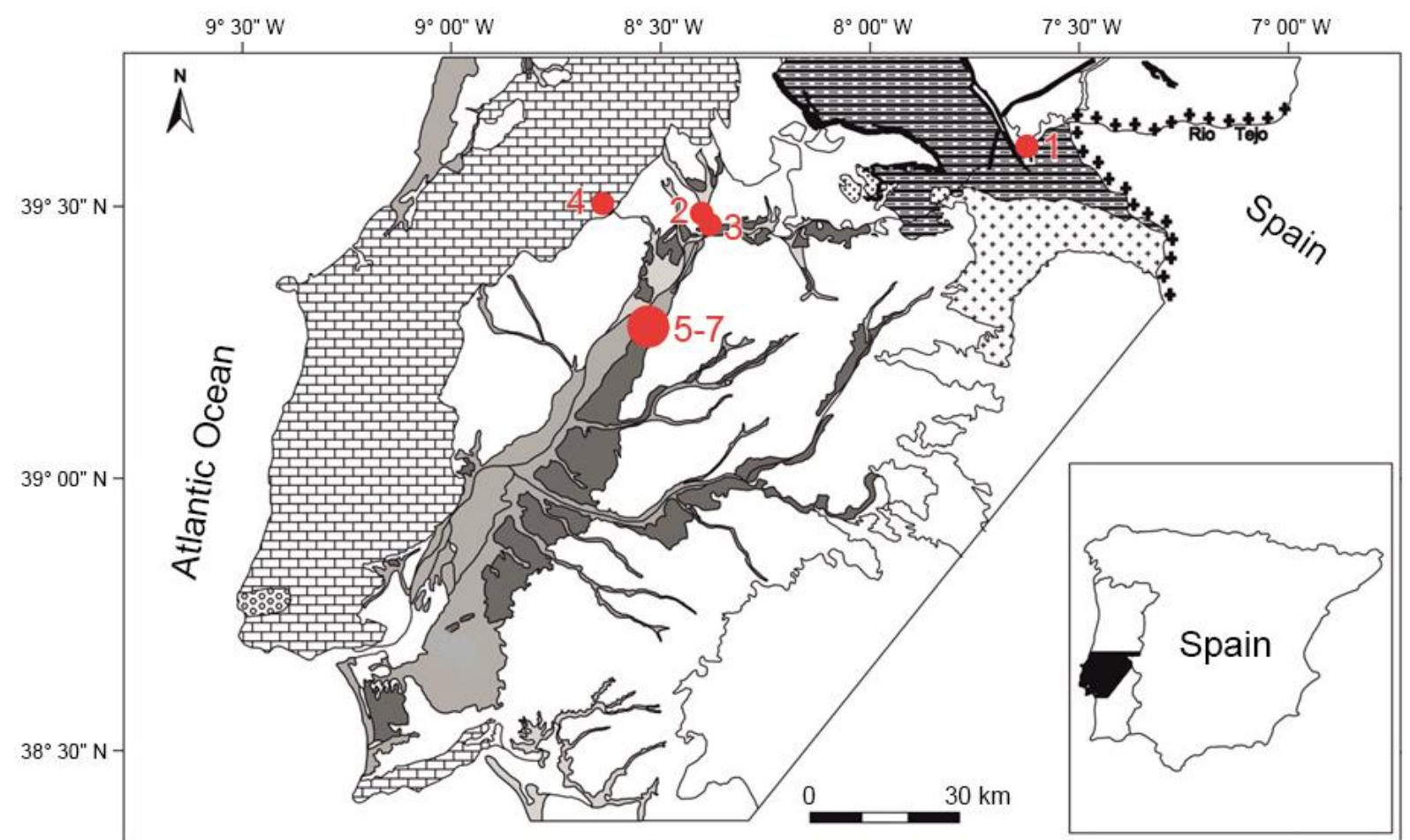

Figure 1. Sites in Central Portugal mentioned in the text: 1. Monte Famaco; 2. RPP; 3. Fonte da Moita; 4. Aroeira; 5-7. Vale do Forno 1, 3 and 8.

In summary, following typological criteria, the lithic industries of the sites are considered as representative of a Palaeolithic cultural sequence ranging from the Middle Acheulian to the Micoquian (Mozzi et al. 2000: 365).

Also in the Tagus valley, in the region of Vila Velha de Rodão, recently published detailed geomorphologic studies provide a more precise age for the archaeological materials from the site of Monte Famaco, recently considered to represent the T4 terrace (middle terrace) of a suite of six terraces identified at the Lower Tagus Basin and dated (IRSL) between 280-136 ka (Cunha et al. 2008; Martins et al. 2009). Two series of lithic industries were identified at Monte do Famaco (GEPP 1977; Raposo 1987; 1993). One comes from the T4 terrace, which is made up of a 1-m thick clast-supported gravel-boulder conglomerate, with poor sorting (Cunha et al. 2008). The assemblage is composed of thirty-four worn-out quartzite artifacts tentatively "attributed to the early Middle Acheulean (Lower Palaeolithic)" (Cunha et al. 2008: 47; Raposo 1987). The second series of 1500 artifacts was collected from a colluvial deposit at the top of the terrace. Though never extensively published, this assemblage includes, among other lithic morphologies, a high quantity of bifaces and cleavers (Raposo et al. 1993). 
An exception to the open air contexts is the Aroeira Cave. This cave belongs to the Almonda karst system and is located in a south-facing cliff, near Torres Novas in the Portuguese Estremadura region. The excavation of this site started in the early 1990s and the currently published data indicates the existence of a series of geological units within the brecciated deposits (Marks et al. 1999; 2002a; 2002b). These units present five stratigraphic layers that yielded a dense quantity of lithic and bone remains. The Middle Pleistocene chronology of this site is testified by the characteristics of the faunal assemblage and several absolute dates ranging between $400 \mathrm{ka}$ and $250 \mathrm{ka}$ years ago (Hofman et al. 2013; Marks et al. 2002b). The bone record of this site contains the most ancient human remains identified so far in the Iberian Atlantic coast. Two archaic human teeth, a mandibular canine and a maxillary third molar, were recovered and are considered as being similar to those of other Middle Pleistocene European humans, still a more precise identification at the species level was not possible (Trinkaus et al. 2003). The lithic assemblage of Aroeira, is strikingly distinct from the others. Though essentially made on local raw materials (quartzite, quartz) it also has others local raw materials such as flint and limestone. It contains some artifacts considered as typical Acheulian. Use of the Levallois method is evident, but not as extensively as the discoid method. The authors underline the important component of small asymmetric bifacial tools, partly bifacial tools (points) and bifacial retouched knives, that are, from a morphological point of view, typical of the Micoquian (Keilmessergruppe) of central Europe (Marks 2005). According to the extensive cutmarks and other modifications found on faunal bones, extensive butchering and defleshing took place on the site; the assemblages may represent the material remains of, if not base camps, than of camp sites where a range of activities took place.

\subsection{The Ribeira da Ponte da Pedra site and its geological setting}

The RPP archaeological site, also known as Ribeira da Atalaia, is located in the valley of Ribeira (Portuguese for "stream") da Ponte da Pedra, a right tributary of the Tagus River in Central Portugal. It is in a region extending along the middle and lower Tagus River valley known as High Ribatejo (Figure 2).

This region comprises three main geological units: 1) the Pre-Cambrian and Palaeozoic schist-metamorphic complex (Ancient Massif); 2) the "Estremenho" Limestone massif, which is essentially Mesozoic with some Cenozoic deposits; 3) the Tagus Cenozoic sedimentary basin.

The regional quaternary deposits are composed of recent alluvial sediments, Pleistocene fluvial terraces, karstic cave fillings (in the limestone massif), and detritic covers.

This hydrological network is shaped by regional tectonics and, accordingly, the larger Tagus tributaries come from the North. The small Ponte da Pedra stream also flows from North to South and its valley has been totally excavated within the Tagus sedimentary basin and hence is characterised by fluvial-lacustrine detritic sediments from the Cenozoic (Miocene).

Until the Middle Pleistocene, the valley was longer than at present and continuous with the Nabão Valley. Presently, the stream valley is only a few kilometres $(8-9 \mathrm{~km})$ shorter.

The landscape around RPP is characterized by fluvial terraces covering the slopes of the nearby low hills, which are less than $140 \mathrm{~m}$ high. The excavations taken during 10 field seasons exposed four geological units (from the oldest to the youngest): Miocene substrate, bottom of T4 fluvial terrace, top of T5 fluvial terrace and colluvial covering. 

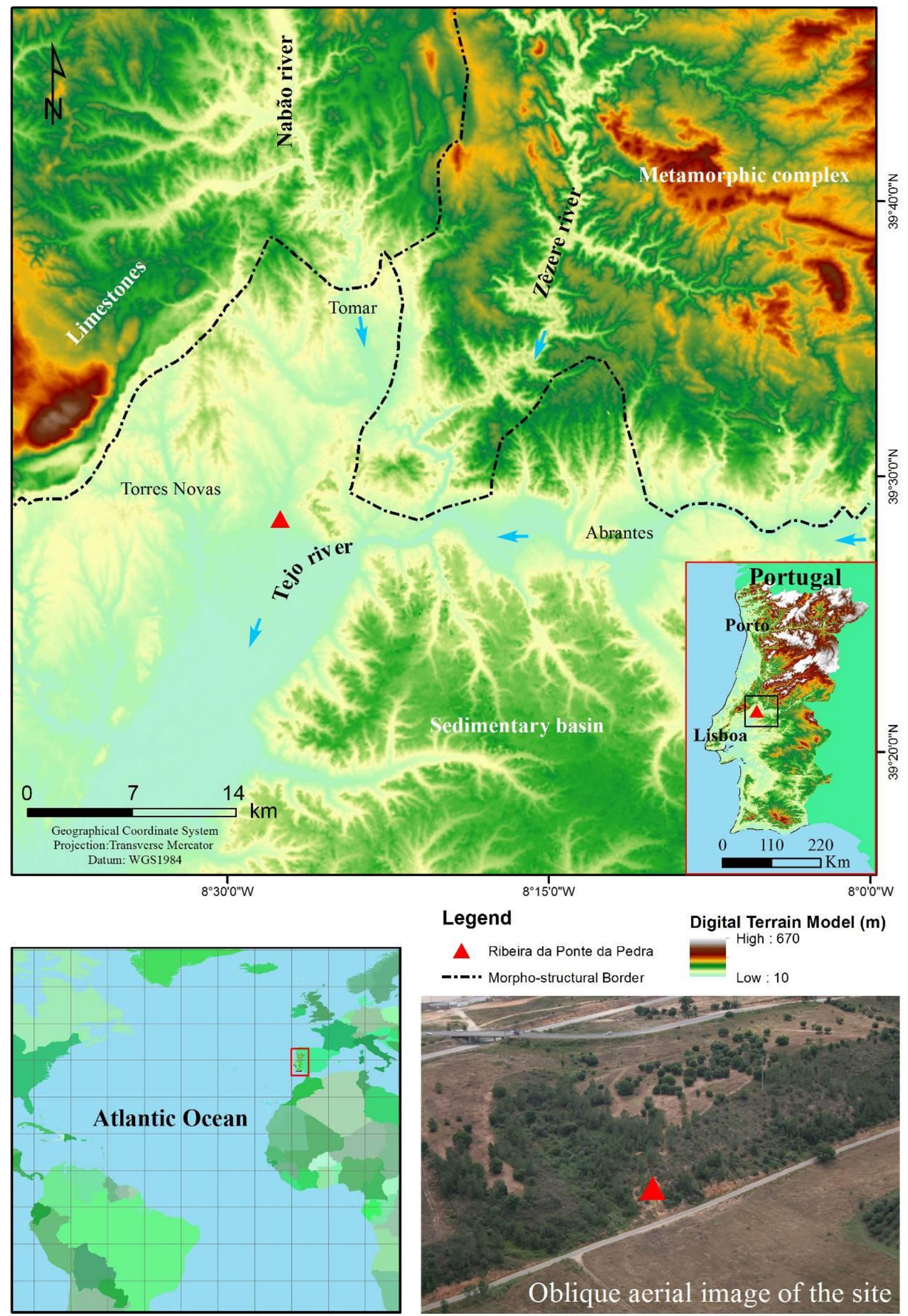

Figure 2. Ribeira da Ponte da Pedra: location of the site (red triangle). Geographical coordinate system projection: Transverse Mercator. Datum: WGS1984. 
The T4 fluvial terrace bottom (from where the artefacts presented in this paper were recovered) is formed by, at least, four different depositional morphologies: a bar (formed by reddish coarse sand and pebbles); a channel (filled with big pebbles and cobbles, up to $35 \mathrm{~cm}$, and reddish coarse sand) that cuts the bar; fine grained flood plain deposits (grey to yellow); and transverse channels (filled with reddish sand and pebbles, up to $10 \mathrm{~cm}$ ) that have a very erosive contact with lower fine sands, these morphologies comprise 11 different lithological units (Table 1, Figure 3) (Rosina \& Cura 2010; Rosina et al. 2011).

Table 1. Lithological Units description and geo-archaeological interpretation. Abbreviation: unc. - uncertain.

\begin{tabular}{lllll}
\hline UL & Sediments & Interpretation & Artefacts & Geo-archaeology \\
\hline 20 & Coarse sands & Colluviums & Present & Reworked (unc.) \\
46 & Sands & Transversal channel & Very rare & Transported \\
47 & Fine sands and silts & Floodplain or Overbank & Very rare & Not transported \\
& Palaeosurface (unc.) & & & \\
48 & Sands and pebbles & Bar? & Present & (unc.) \\
49 & Sands and gravels & Channel Fill & Abundant & Transported \\
60 & Fine sands and silts & Floodplain or Overbank & Very Rare & Not transported \\
& Palaeosurface (unc.) & & & \\
42 & Fine sands and silts & Floodplain or Overbank & Absent & \\
45 & Sands and pebbles & Channel Fill & Rare & Transported \\
50 & Para-conglomerate & Channel & Abundant & Mass transported \\
30 & Sands and gravels & Bar & Rare & Removed \\
99 & Conglomerate layers & Lag deposits & Very Rare & Removed \\
\hline
\end{tabular}

According to previous attributions (Rosina 2002, 2004), partially confirmed by OSL (304 $437 \pm 19595 \mathrm{BP})$, IRSL $(175 \pm 6 \mathrm{ka})$ and ERS $(260 \pm 35 ; 264 \pm 39)$ dating of lithological unit 47 (see Figure 3) (Dias et al 2010; Martins et al 2010; Rosina et al 2014), the T4 fluvial terrace could be associated with OIS 8 and 9. The large chronological range of the different absolute dates are related with the nature of the different dating methods and feeding, respectively IRSL (age underestimated), OSL and ESR. We consider in our interpretation of the site and lithic assemblage chronology the results of the ERS dating (Rosina et al 2014).

\subsection{The lithic assemblage}

The lithic industry found at the bottom of the T4 fluvial terrace (1259 artefacts), is essentially characterized by three major groups: worked pebbles; non-retouched blanks; retouched blanks and blanks with 'atypical' edge modification (flakes and pebbles showing macro-scars that cannot be ascribed to regular retouch due to their irregular morphology, dimension, and sequence), and a minor group of associated cores and bifacial and unifacial tools. Even if rare, Unifacial and Bifacial Large Cutting tools (Table 2) as well as predetermined cores (from very large to very small) are present in the assemblage, indicating the knowledge of these more 'complex' technologies.

These groups should be considered together as the technological result of two main reduction sequences: small pebbles that were retouched mainly to be used as notches, and pebbles that have been knapped in order to produce flakes (mainly cortical or half-cortical), eventually these pebbles were also knapped and used as heavy duty tools (choppers) (Figure 4). The main debitage method is recurrent unifacial and unidirectional with hard hammer and direct percussion technique. 
B44

B43

B42

B41

B40

B37

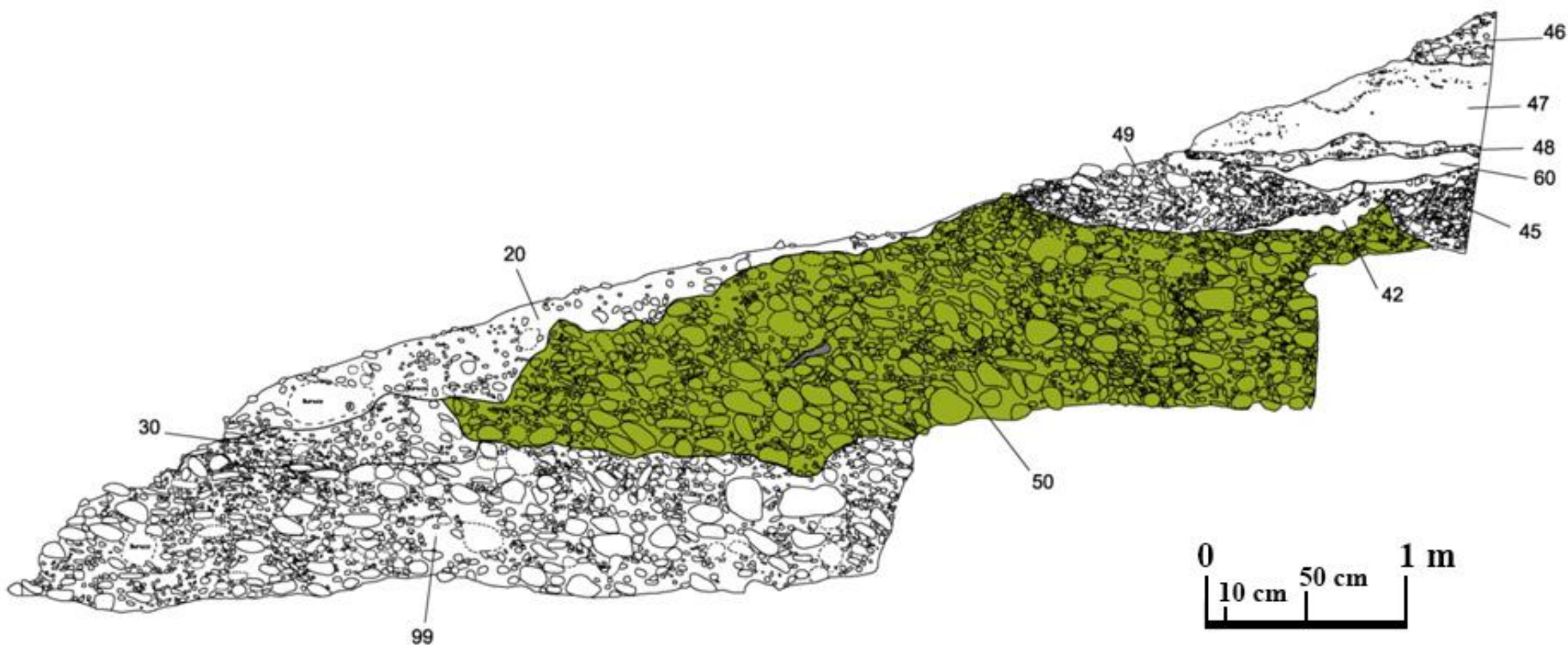

Figure 3. Stratigraphy of the site (in green the main lithological unit of artefacts provenance). 
Table 2. Main techno-typological lithic categories.

\begin{tabular}{lc}
\hline Blank & Total percentage \\
\hline Unifacial worked pebble & $8,40 \%$ \\
Bifacial worked pebble & $0,90 \%$ \\
Uniface & $0,10 \%$ \\
Bifacial tool on pebble & $0,20 \%$ \\
Bifacial tool on flake & $0,10 \%$ \\
Cores & $1,40 \%$ \\
Centripetal core & $0,50 \%$ \\
Discoidal core & $0,20 \%$ \\
Flake core & $0,10 \%$ \\
Prismatic core & $0,10 \%$ \\
Bifacial core & $0,20 \%$ \\
Multifacial core & $0,20 \%$ \\
Unretouched Flake & $36,30 \%$ \\
Retouched flake & $14,50 \%$ \\
Retouched pebble & $6,80 \%$ \\
Fragments and debris & $30,20 \%$ \\
\hline
\end{tabular}

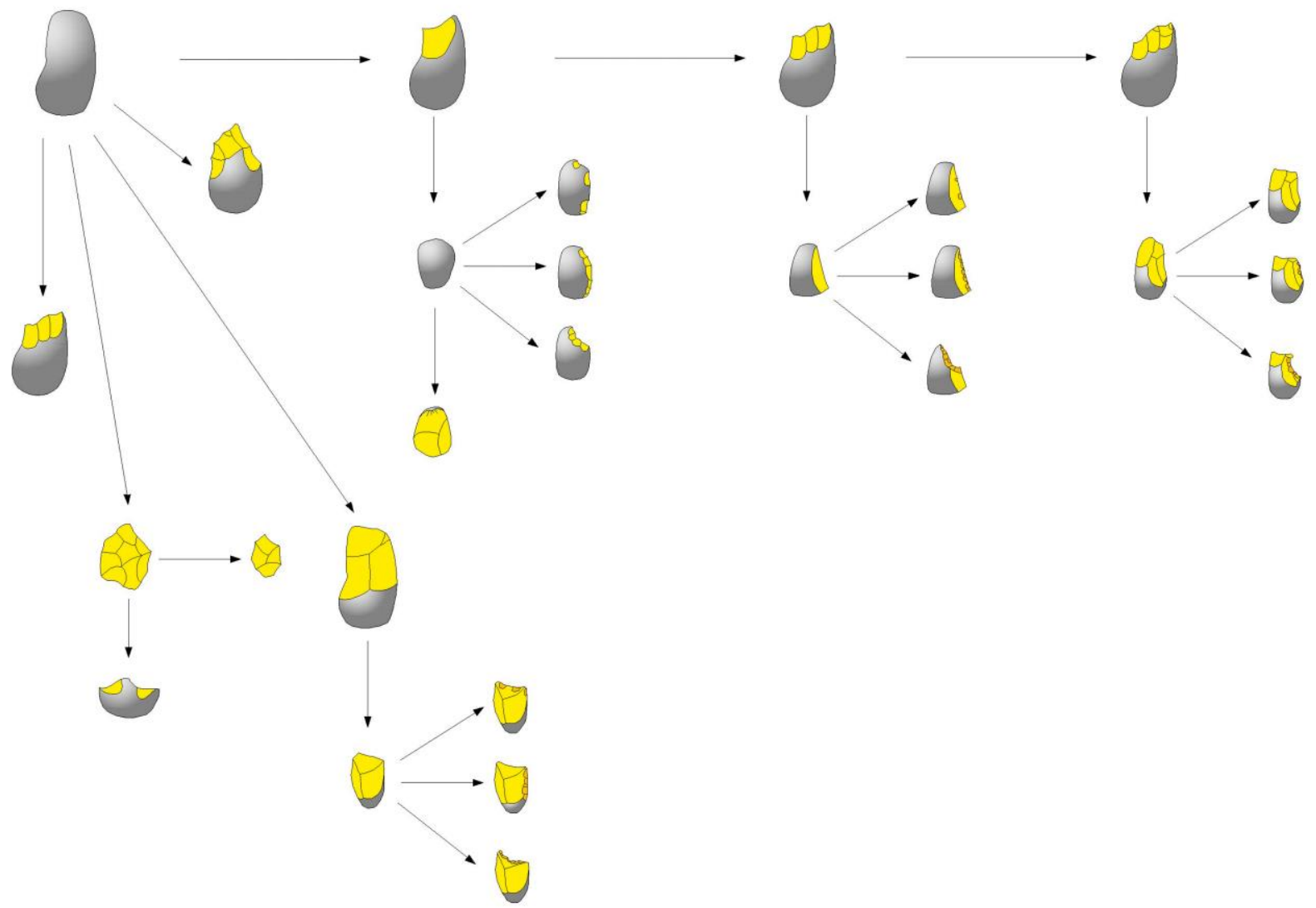

Figure 4. Reduction sequences and their variants recorded in Ribeira da Ponte da Pedra.

The scars on the worked pebbles and cores rarely out number 4 removals. We consider this as an achieved techno-functional goal for the production of cortical blanks, as well as a less economic behaviour given the large availability of local raw material (Table 3). The main knapping method consists on the removal of a first flake on one of the sides of the pebble, a 
second flake is removed on the other side using part of the negative of the first flake thus presenting a morphology in "quartier d'orange", a third central flake is removed in the intersection of the two initial removals, presenting quadrangular or triangular morphologies.

Table 3. Total percentage of worked pebbles and their removals. The total is in relation with the total percentage of the lithic assemblage.

\begin{tabular}{lc}
\hline Technologic category & Total* \\
\hline Pebble with one removal & $3,40 \%$ \\
Pebble with 2 or 3 unifacial removals & $3,70 \%$ \\
Pebble with 2 or 3 bifacial removals & $0,50 \%$ \\
Pebble with 4 or more unifacial removals & $1,30 \%$ \\
Pebble with 4 or more bifacial removals & $0,40 \%$ \\
\hline
\end{tabular}

When the frequencies of blank categories are compared, we observe a lower percentage incidence of non-cortical blanks (Cura \& Grimaldi 2009).

Retouched blanks are mainly on cortical or half cortical flakes and some on worked pebbles (Figure 5). Their percentage decreases along with the reduction of cortex presence, being less among non-cortical flakes. This seems to suggest that flakes showing modified edges were mainly in the cortical flakes category. (Table 4).

The analysis of the modified edges of the different blanks shows the presence of marginal or invasive, coarse and irregular alterations, quite variable in its position and location that we consider as 'atypical' (Table 4 and 5). These modifications do not correspond to a formal regular retouch and therefore this artifacts do not fit the 'classic types' of the F. Bordes (1961) formal tools. This exclusion from conventional typological list, however, doesn't exclude these blanks as informal functional tools.

Considering the fluvial context of the lithic assemblages we didn't exclude eventual edge modifications resulting from post-depositional processes (Chambers 2003; Hosfield \& Chambers 2002). However, even if 'atypical' these modifications do not occur in all blanks of the assemblage and, observing its technical and functional features, we consider that they don't represent a consequence of this type of phenomena. They do not resemble isolated abrupt removals in the more fragile margins caused by fluvial transport and shock.

Therefore we question whether these 'atypical' features are an intentional edge modification by irregular retouch or, on the other hand, are mechanical alterations as a consequence of the utilization of these blanks. To help clear up this question we carried out an experimental program with a series of 7 worked pebbles used to cut and fracture hand axelike, and 68 large and medium sized flakes used to cut and fracture hand axe-like, scrap, saw and engrave. The materials worked were large fresh Bos taurus, Capra hircus, Ovis aries and Sus scrofa bones, fresh Quercus ilex, fresh Salix alba and fresh Quercus ilex without outer bark. The results so far obtained allow us to consider that most of the edges described as "atypical" edge modification might be the consequence of functional activities (Figures 6 and 7) linked to different subsistence tasks, namely those involving hard materials like wood and bone (Cristiani 2010; Cura 2014; Cura et al. 2014). However this possibility must be reinforced by further experimentations and traceological analysis. Over a selected sample of 47 flakes, 17 were characterised by less developed post-depositional alteration and were subject to functional analyses. The results indicate the activities of cutting, scraping and a combination of cutting and scraping. The worked materials were hard and medium hard and soft (Cristiani et al. 2010). 

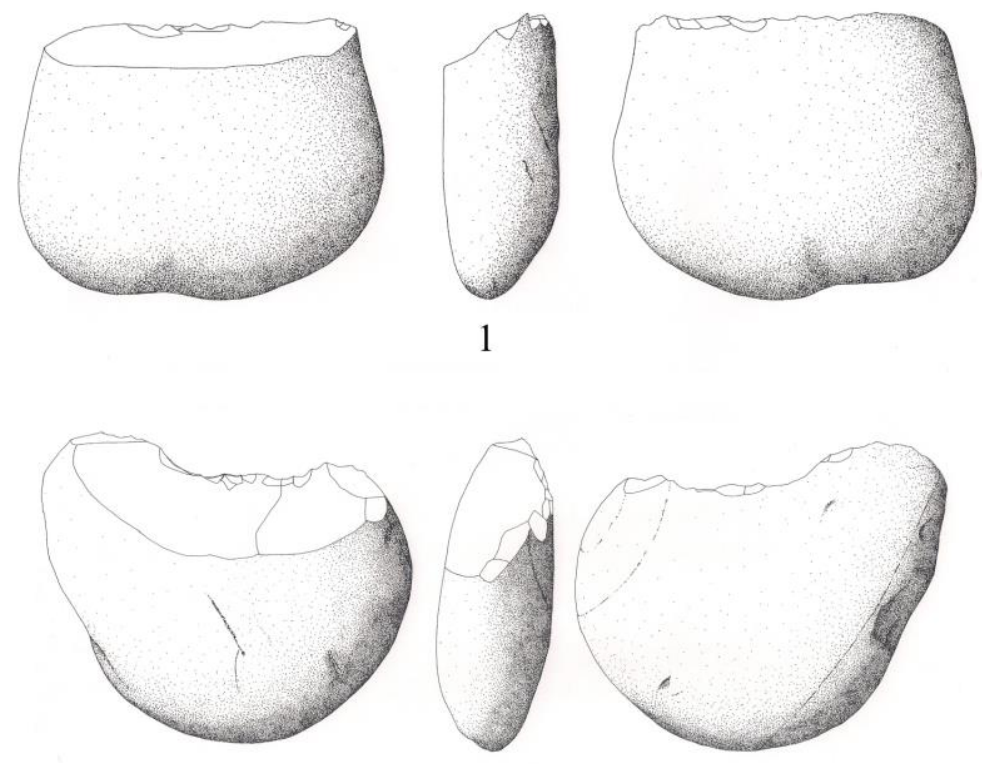

2
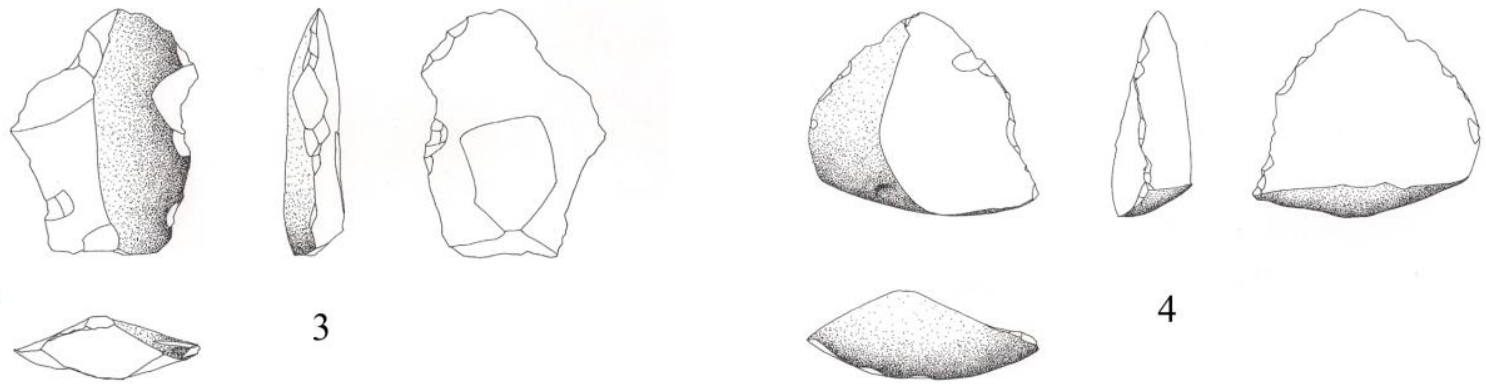

3

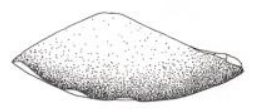

4

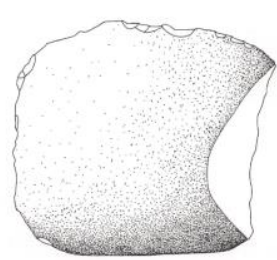

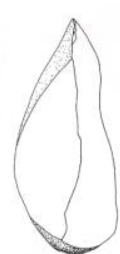

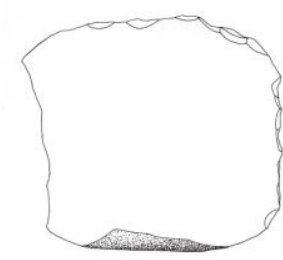

5
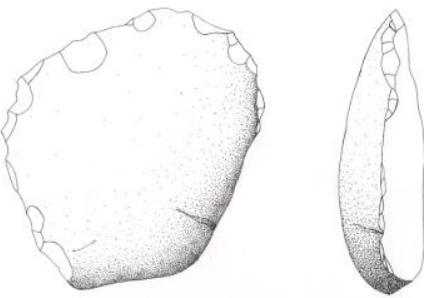

6

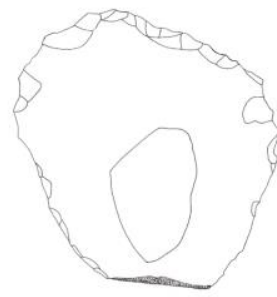
$5 \mathrm{~cm}$
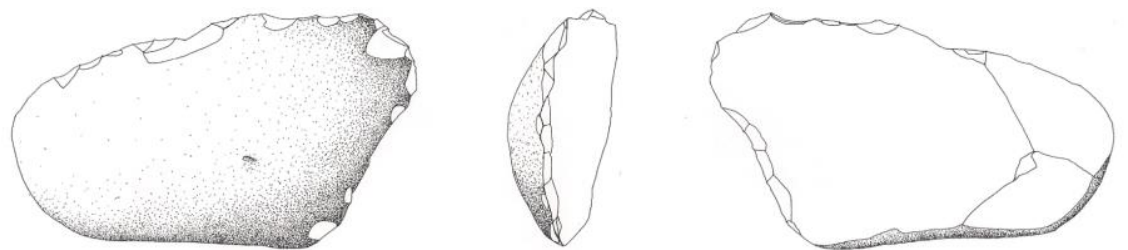

7

Figure 5. Lithic artifacts from RPP: 1 - Retouched pebble; 2 - Worked Pebble; 3 - Double notch on flake; 4-5 Retouched flakes; 6-7 - Informal retouched flakes. 
Table 4. Relation between flake technological category and edge modification morphology.

\begin{tabular}{|c|c|c|c|c|c|c|c|c|c|c|c|c|}
\hline \multirow[b]{3}{*}{ Technologic category } & \multicolumn{10}{|c|}{ Edge modification morphology } & \multirow{2}{*}{\multicolumn{2}{|c|}{ Total }} \\
\hline & \multicolumn{2}{|c|}{ Notch } & \multicolumn{2}{|c|}{ Sub-parallel } & \multicolumn{2}{|c|}{ Denticulate } & \multicolumn{2}{|c|}{ Clactonian notch } & \multicolumn{2}{|c|}{ Atypical } & & \\
\hline & No. & $\%$ & No. & $\%$ & No. & $\%$ & No. & $\%$ & No. & $\%$ & No. & $\%$ \\
\hline Cortical Flake & 10 & $58,8 \%$ & 42 & $54,5 \%$ & 16 & $57,1 \%$ & 4 & $44,4 \%$ & 77 & $43,5 \%$ & 149 & $48,4 \%$ \\
\hline Cortical flake ( $75 \%$ of cortex) & 1 & $5,9 \%$ & 10 & $13,0 \%$ & 3 & $10,7 \%$ & & & 34 & $19,2 \%$ & 48 & $15,6 \%$ \\
\hline Half cortical flake ( $50 \%$ de cortex) & 1 & $5,9 \%$ & 7 & $9,1 \%$ & & & & & 33 & $18,6 \%$ & 41 & $13,3 \%$ \\
\hline Partial cortical flake ( $25 \%$ to $50 \%$ of cortex) & 2 & $11,8 \%$ & 2 & $2,6 \%$ & & & & & 11 & $6,2 \%$ & 15 & $4,9 \%$ \\
\hline Partial cortical flake ( $25 \%$ of cortex ) & 1 & $5,9 \%$ & 5 & $6,5 \%$ & 3 & $10,7 \%$ & 4 & $44,4 \%$ & 5 & $2,8 \%$ & 18 & $5,8 \%$ \\
\hline Non-cortical flake (cortical butt) & & & 6 & $7,8 \%$ & 3 & $10,7 \%$ & & & 9 & $5,1 \%$ & 18 & $5,8 \%$ \\
\hline Non-cortical flake & 2 & $11,8 \%$ & 5 & $6,5 \%$ & 3 & $10,7 \%$ & 1 & $11,1 \%$ & 8 & $4,5 \%$ & 19 & $6,2 \%$ \\
\hline Total & 17 & $100 \%$ & 77 & $100 \%$ & 28 & $100 \%$ & 9 & $100 \%$ & 177 & $100 \%$ & 308 & $100 \%$ \\
\hline
\end{tabular}

Table 5. Total number and percentages of Non retouched, retouched and "atypical" retouch of the lithic assemblage.'

\begin{tabular}{lcccccccc}
\hline Blank & \multicolumn{2}{c}{$\begin{array}{c}\text { Non retouched } \\
\end{array}$} & No. & \multicolumn{2}{c}{ Retouched } & \multicolumn{2}{c}{ 'Atypical' edge modification } & \multicolumn{2}{c}{ Total } \\
& No. & \% & No. & \% & No. & \% \\
\hline Worked pebble & 96 & $12 \%$ & 9 & $4 \%$ & 12 & $5 \%$ & 117 & $9 \%$ \\
Retouched pebble & & & 67 & $29 \%$ & 26 & $11 \%$ & 93 & $7 \%$ \\
Flake & 459 & $58 \%$ & 131 & $57 \%$ & 177 & $76 \%$ & 769 & $61 \%$ \\
Core & 37 & $5 \%$ & & & 2 & $3 \%$ & 39 & $3 \%$ \\
Bifacial tools & 2 & $0,30 \%$ & & & 2 & $1 \%$ & 4 & $0 \%$ \\
Fragments and Debris & 203 & $25 \%$ & 21 & $9 \%$ & 13 & $6 \%$ & 237 & $19 \%$ \\
\hline Total & $\mathbf{7 9 7}$ & $\mathbf{6 3 \%}$ & $\mathbf{2 2 8}$ & $\mathbf{1 8 \%}$ & $\mathbf{2 3 2}$ & $\mathbf{1 8 \%}$ & $\mathbf{1 2 5 9}$ & $\mathbf{1 0 0 \%}$ \\
\hline
\end{tabular}



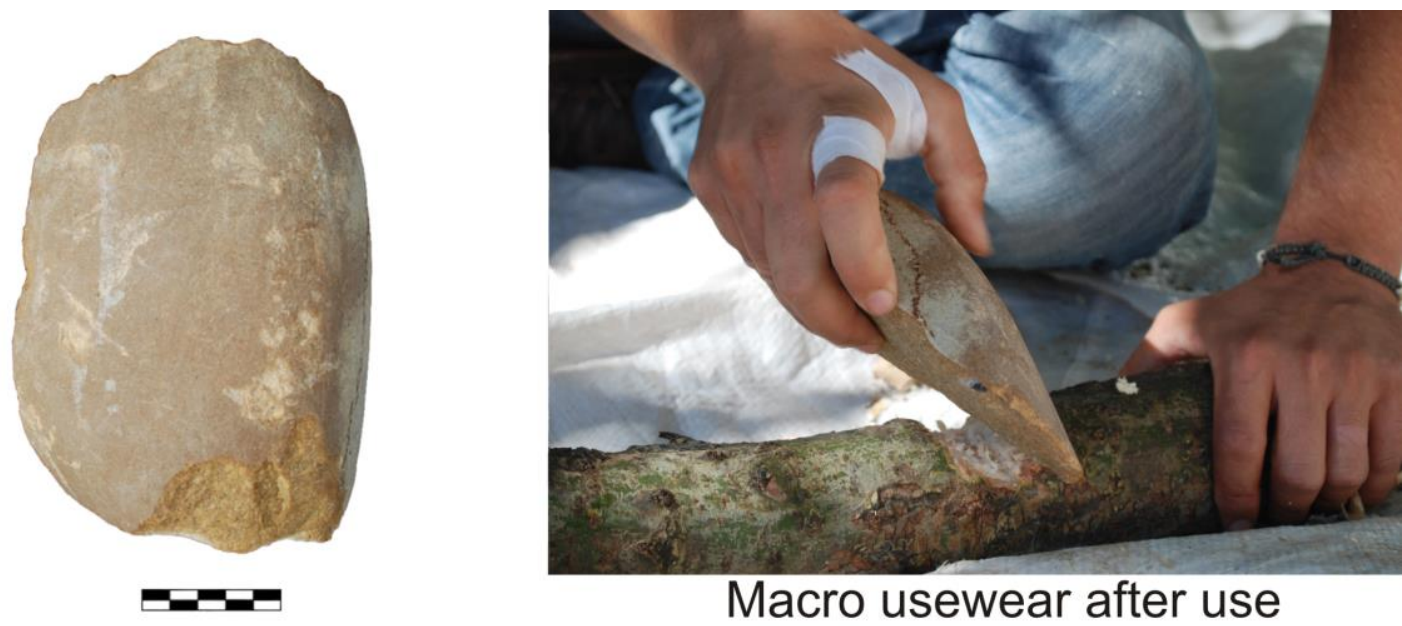

\section{Macro usewear after use}
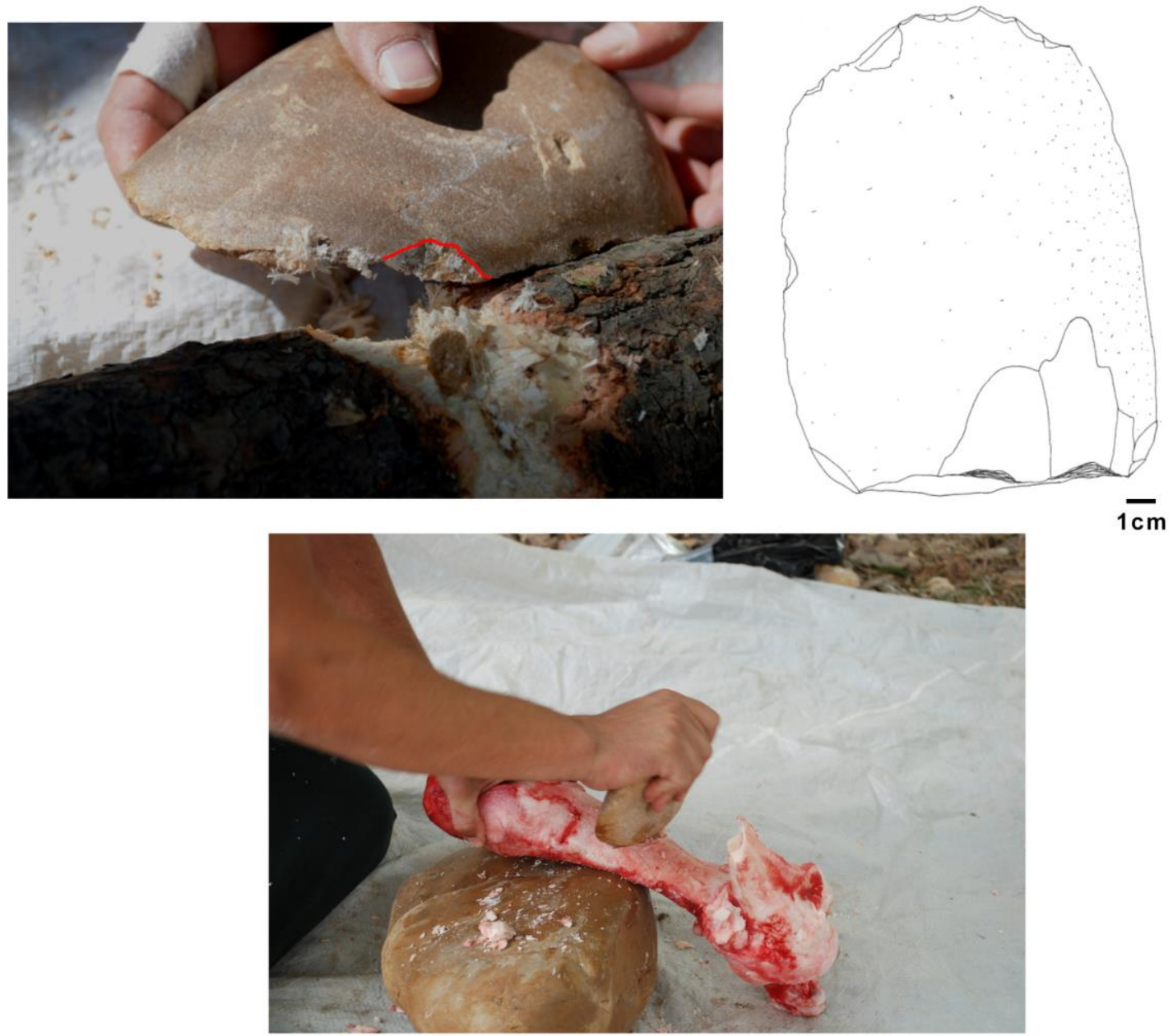

$\overline{1 \mathrm{~cm}}$

\section{Macro usewear after use}
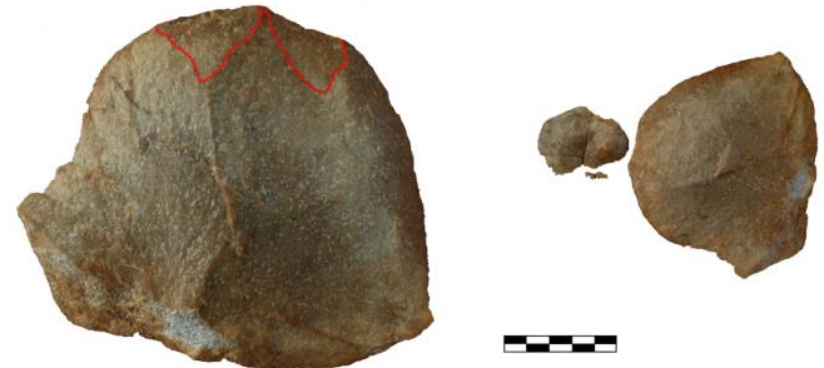

Figure 6. Experimental cutting of wood (fresh Quercus ilex with outer bark) and bone (fresh Bos Taurus) with cortical flakes. 


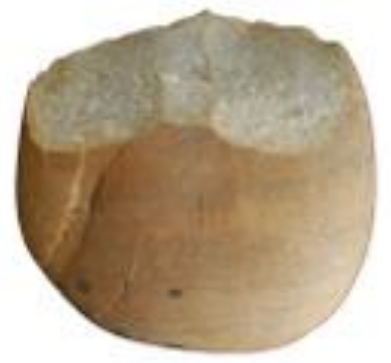

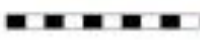
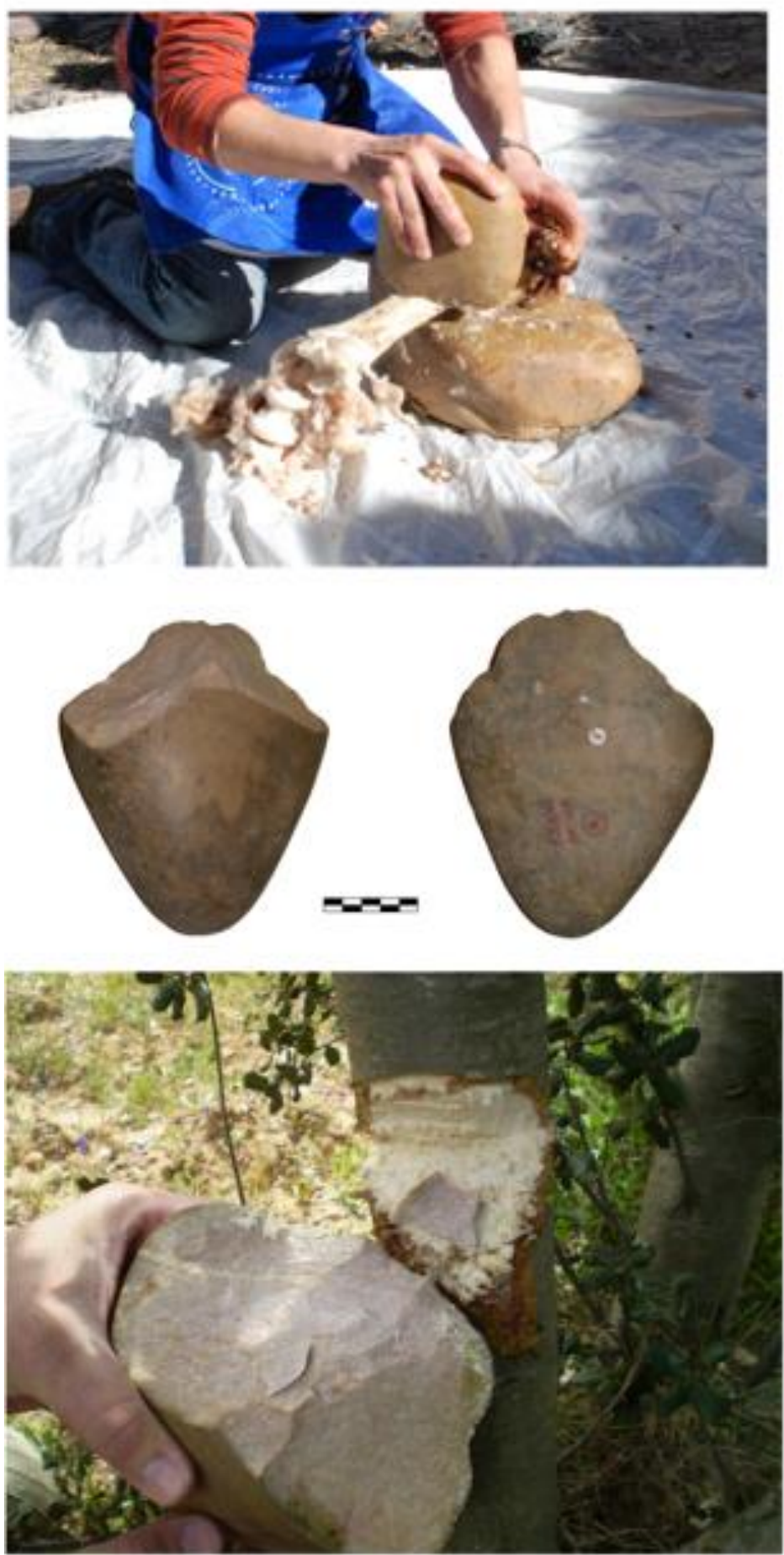

Figure 7. Experimental cutting of wood (fresh Quercus ilex with outer bark) and bone (fresh Bos Taurus) with worked pebbles. The scale bars are divided into $1 \mathrm{~cm}$ sections.
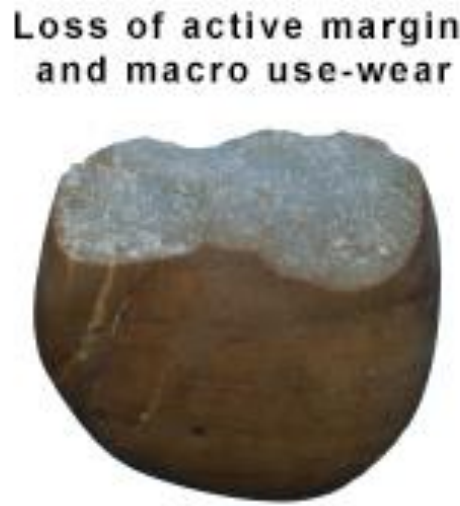

a

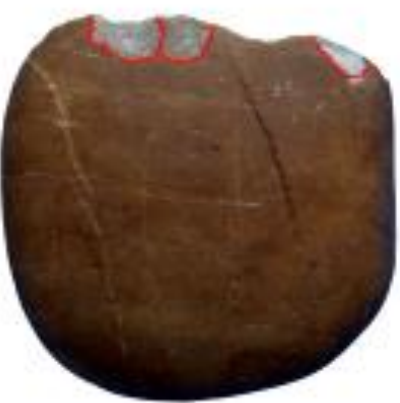

\section{Loss of active margin and macro use-wear}

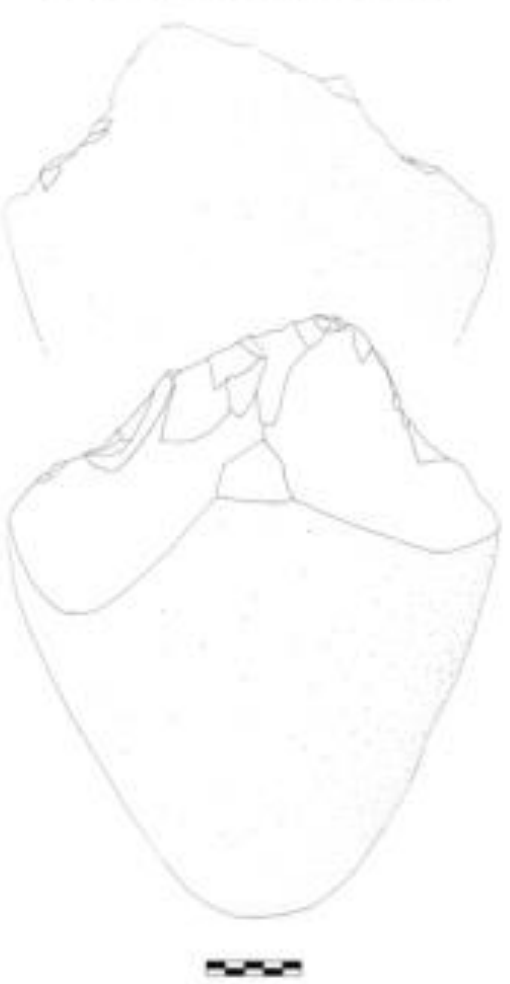




\section{Materials and methods}

A sample of 250 'natural' pebbles (Figure 8) were collected from the T4 fluvial terrace deposits in the surroundings of the site were the same lithological units were present. (Figure 9). This sample was compared with 83 archaeological worked pebbles that had 1 or 2 removals that had not altered significantly the original morpho-volumetry of the pebbles.

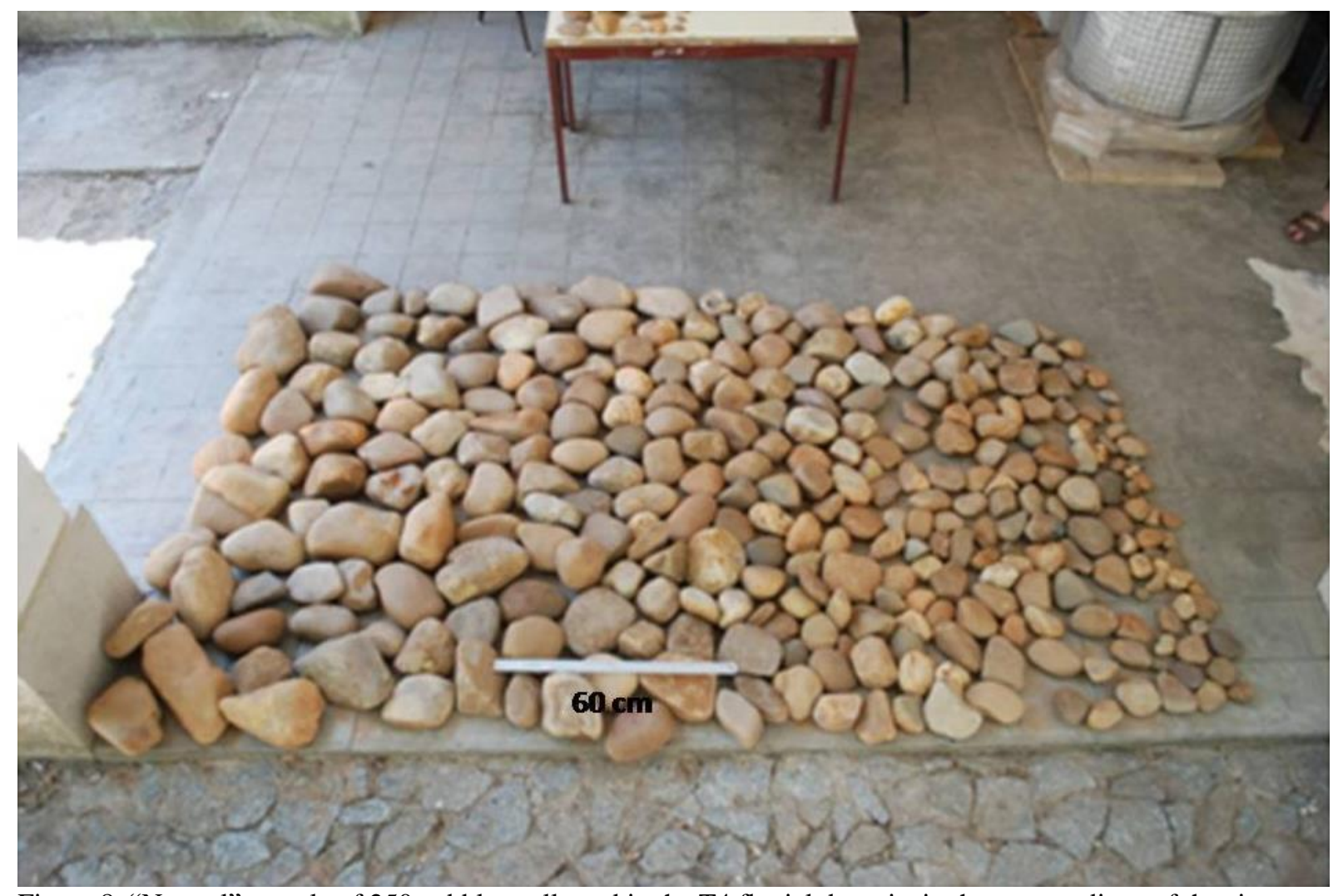

Figure 8. "Natural" sample of 250 pebbles collected in the T4 fluvial deposits in the surroundings of the site.

\section{Morphometry}

angular subangular subrounded rounded

High sphricity
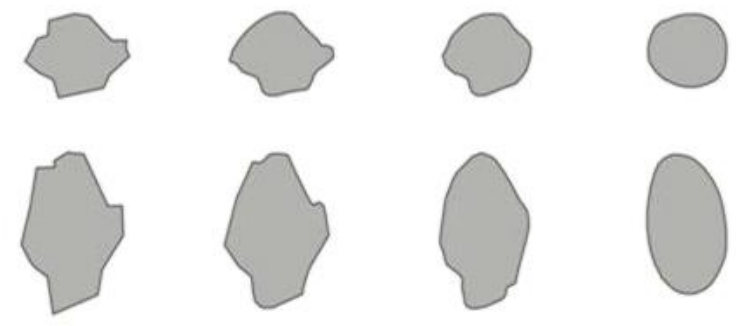

Low Sphericity


\section{Volumetry (section)}

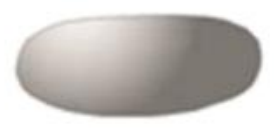

oblong

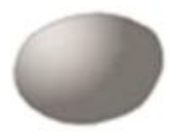

cylindical

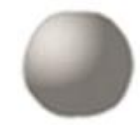

globular

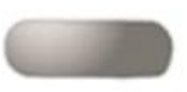

tabular

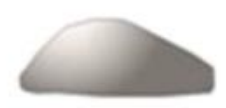

plano-convex

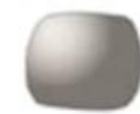

quandrangular

Figure 9. Morphometry and volumetry in section pebbles parameters of analyses. 
All the 250 pebbles were analysed in the same way as the archaeological ones. The maximum length, width and thickness were measured. The morpho-volumetry was classified in morphometry according to high sphericity angular, high sphericity sub-angular, high sphericity sub-rounded, high sphericity rounded; low sphericity angular, low sphericity subangular, low sphericity sub-rounded, low sphericity rounded. The volumetry in section was classified as oblong, cylindrical, globular, tabular, plano-convex and quadrangular (Figure 9). All the "natural" pebbles were knapped in order to verify their texture. The parameters were: vitreous, fine, fine to medium, medium, medium to coarse, coarse, micro-crystalline, or conglomeratic. The texture was macroscopically analysed verifying the visibility of the quartz grains.

\section{Data results and intepretation}

Regarding the quartzite pebble texture, the most represented types in the archaeological sample are also the most frequent in the 'natural' sample, but in this one the values of fine texture are equal to the medium-coarse, barely represented in the archaeological sample. Pronounced selection was not evident, but coarse textures were more present in the "natural" sample indicating that these were not selected by the knappers who took advantage of the most abundant fine to medium grained pebbles that were more suitable for knapping and further utilization in the production of blanks (Table 6).

Table 6. Distribution of the observed textures in the archaeological sample in comparison with the 'natural' sample.

\begin{tabular}{lcc}
\hline Texture & $\begin{array}{c}\text { Archaeological Sample } \\
\%\end{array}$ & $\begin{array}{c}\text { 'Natural' Sample } \\
\%\end{array}$ \\
\hline Vitreous & $0,20 \%$ & $0,80 \%$ \\
Fine & $22,40 \%$ & $14 \%$ \\
Fine to Medium & $43,20 \%$ & $43,20 \%$ \\
Medium & $25,20 \%$ & $14,40 \%$ \\
Medium to coarse & $5,50 \%$ & $14 \%$ \\
Coarse & $1,90 \%$ & $4,80 \%$ \\
Macro-crystalline & $1,60 \%$ & $6,40 \%$ \\
Conglomeratic & & $2 \%$ \\
Other & & $0,40 \%$ \\
\hline Total & $\mathbf{1 0 0} \%$ & $\mathbf{1 0 0 \%}$ \\
\hline
\end{tabular}

The observation of the morphometry seems to indicate a criteria of preference and selection; the most commonly found in the archaeological sample (low sphericity subrounded) is not the most abundant in the "natural" sample. This option might indicate a selection based on the technical objectives of exploitation found in this morphometry, which has the most suitable angles for the regular production of blanks (this fact was confirmed by us in repeated knapping experiments). The second most used morphometry in the archaeological sample is the most present in the natural "sample", and does not indicate a criteria of selection of this particular morphometry. We verified a more pronounced difference in the high presence of pebbles of high sphericity sub-rounded in the 'natural' sample, which present a low percentage in the archaeological sample. This seems to be related with the mismatch of this morphometry to knapping exploitation due to the lack of appropriate angles (Table 7), thus clearly indicating a selection between the available pebbles. 
Table 7. Distribution of the observed morphometries in the archaeological sample in comparison with the 'natural' sample.

\begin{tabular}{lcc}
\hline Morphometry & $\begin{array}{c}\text { Archaeological sample } \\
\mathbf{\%}\end{array}$ & $\begin{array}{c}\text { 'Natural’ Sample } \\
\mathbf{\%}\end{array}$ \\
\hline High sphericity angular & $2,20 \%$ & $7 \%$ \\
High sphericitysubangular & $3,10 \%$ & $6,40 \%$ \\
High sphericitysubrounded & $4,90 \%$ & $27,60 \%$ \\
High sphericity rounded & $3,10 \%$ & $4,00 \%$ \\
Low sphericity angular & $11,60 \%$ & $3,60 \%$ \\
Low sphericitysubangular & $14,70 \%$ & $6,20 \%$ \\
Low sphericitysubrounded & $23,20 \%$ & $34,00 \%$ \\
Low sphericity rounded & $30,40 \%$ & $12,00 \%$ \\
Undetermined & $6,70 \%$ & $0,40 \%$ \\
\hline Total & $\mathbf{1 0 0 \%}$ & $\mathbf{1 0 0 \%}$ \\
\hline
\end{tabular}

The volumetry in section does not show pronounced differences between the two samples. There is a high presence of oblong and plano-convex pebbles in the archaeological sample, as well as in the 'natural' one (Table 8). Such observation might indicate that at this level these morphologies were the most suitable for the required technical goals of exploitation for the production of regular blanks.

Table 8. Distribution of the observed volumetries in section in the archaeological sample in comparison with the 'natural' sample.

\begin{tabular}{lcc}
\hline Volumetry (section) & $\begin{array}{c}\text { Archaeological Sample } \\
\%\end{array}$ & $\begin{array}{c}\text { 'Natural' Sample } \\
\%\end{array}$ \\
\hline Oblong & $26,10 \%$ & $21,20 \%$ \\
Cylindrical & $12,20 \%$ & $15,20 \%$ \\
Globular & $4,10 \%$ & $4,80 \%$ \\
Tabular & $5,90 \%$ & $8,00 \%$ \\
Plano-convex & $28,80 \%$ & $20,80 \%$ \\
Quadrangular & $10 \%$ & $16,00 \%$ \\
Undetermined & $14,90 \%$ & $14 \%$ \\
\hline Total & $100 \%$ & $\mathbf{1 0 0 \%}$ \\
\hline
\end{tabular}

There are no significant variations in length and thickness, but we noticed a difference in width. Despite the limited number of artefacts we can advance the hypothesis that among the available pebbles the medium and large, especially those with larger margins, were more commonly selected. This option can be related to the exploitation choices required to produce regular medium-large sized flakes, as well as with the functionality of the worked pebbles used as tools that would have wider active working edges.

\section{Discussion and conclusions}

In Ribeira da Ponte da Pedra, technical objectives might differ from those items traditionally identified as "predetermined" by typological or technological analyses: however, the predetermined technical objectives are represented through appropriate raw material selection and exploitation indicating a good level of foresight and planning in the exploitation of the quartzite pebbles. 
We observe a marked balanced length, width and thickness ratio of the flakes and worked pebbles. This might indicate a functional need based on the metric features of both flakes (Figures 10 and 11) and worked pebbles pointing towards a simple technical exploitation, but predetermined on this level. This is probably linked to the regular production of flakes and with the utilization of both flakes and worked pebbles since the functional analyses and experimental activities revealed that they would be used mainly in the work of hard and medium materials (probably wood and bone) requiring blanks with balanced metric characteristics.

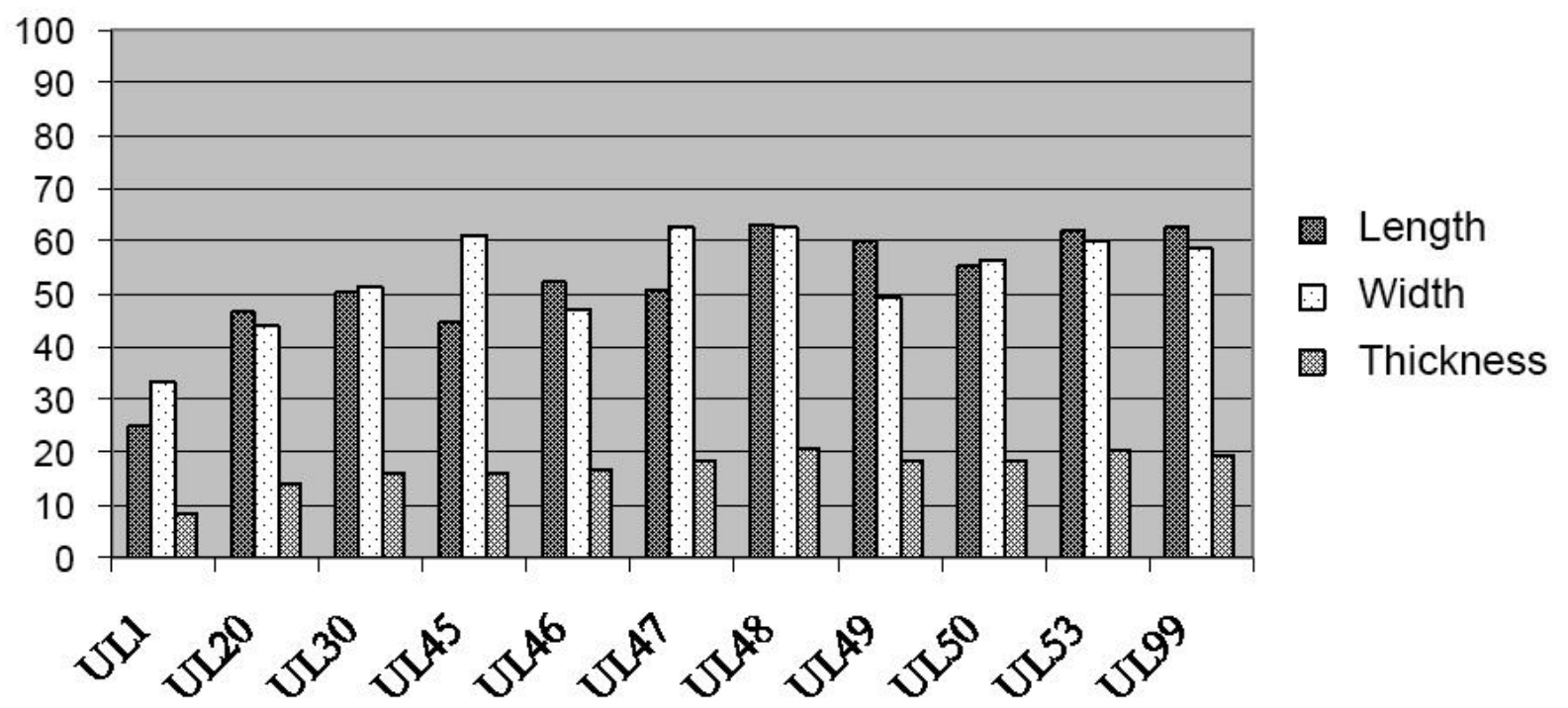

Figure 10. Flake dimensions $(\mathrm{mm})$ distributed by the lithological units that contained flakes.

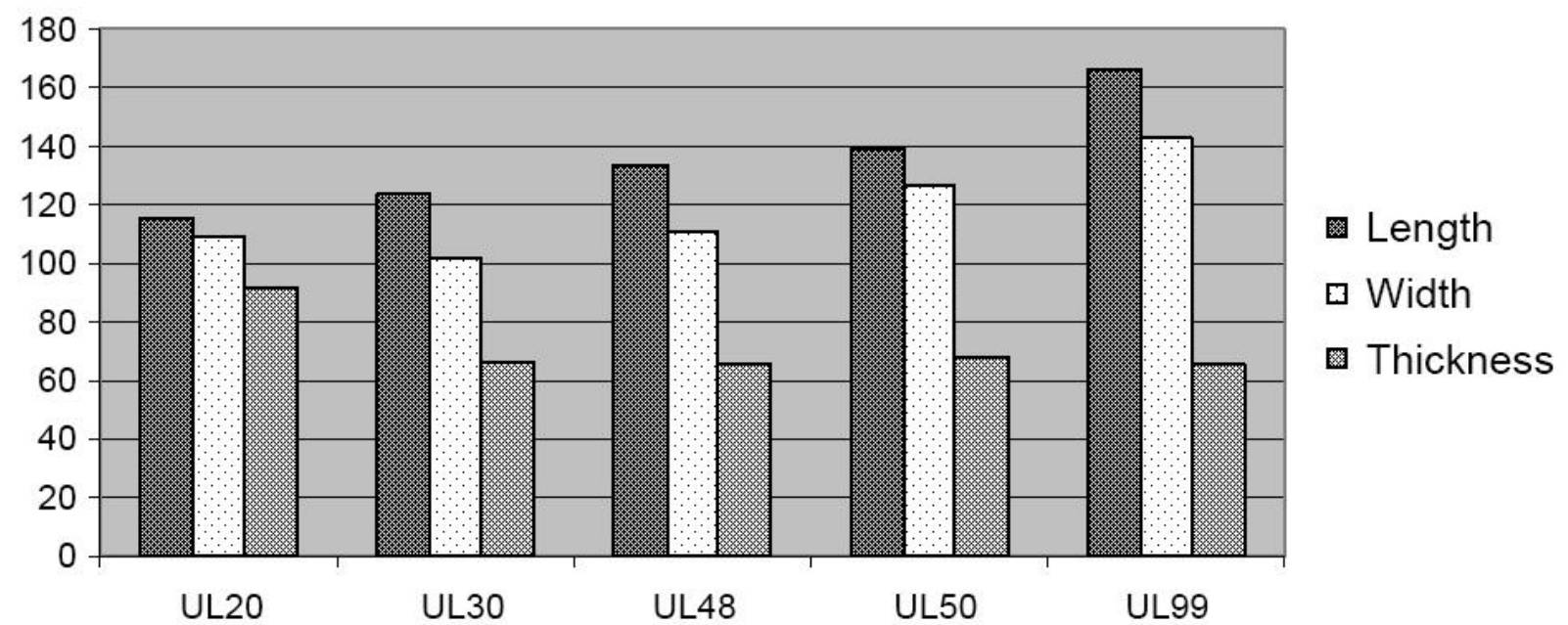

Figure 11. Worked pebbles dimensions $(\mathrm{mm})$ distributed by the lithological units that contained worked pebbles.

The prehistoric knappers have consciously and reasonably profited from the characteristics of the quartzite pebbles (morpho-volumetry and texture) and, particularly, from the good quality of cortical cutting edges. The technical scheme is not simple in the sense that is pre-planned, starting with the selection of the pebbles and the utilization of the regular and appropriate natural angles of exploitation (Rodet et al 2014). The method might be simple, but not simplistic since is chosen and guided by the characteristics and properties of the pebbles to obtain standardized and predetermined blanks. We consider this to be the result of a technical and functional options driven by conscientious choices and goals rather than raw 
material constraints, since the raw material present in the vicinities is of good quality, allowing pursuit of any technical and conceptual choices in the given chrono-cultural context.

In our technological study of the lithic assemblage of the Ribeira da Ponte da Pedra we identified a main reduction sequence that consisted on the unifacial, sometimes bifacial, unidirectional removals on quartzite fluvial pebbles that in terms of technical behaviour is rather simple. Bifacial tools are very rare and cleavers are absent. Despite their very low percentage, various typologies of cores are present.

The features of the lithic industry, which lacks the characteristics typical of the Acheulean techno-complex, and the associated chronology, lead us to advance the question of whether it corresponds to a Final Lower Palaeolithic or to the Middle Palaeolithic (Santonja 2016). The analyses presented here indicate that the raw material characteristics were not a determining factor for the rarity or absence of production of typical façonnage Acheulean elements like bifaces and cleavers. We are in the presence of an industry consisting mainly of worked pebbles, abundant flakes, and a few cores (some centripetal and discoid). Could this be a Final Lower Palaeolithic or transitional industry that ultimately would "evolve" to Middle Palaeolithic and Mousterian techno-complexes?

There is an acknowledged recognition of the coexistence of typical Acheulean and Middle Palaeolithic assemblages in the Final Middle Pleistocene in the Iberian Peninsula, a period that could have been produced by multiple and heterogeneous human adaptive responses (Santonja 2016). In what concerns the RPP site the question remains open to debate, the confrontation with the available data for the Iberian Peninsula, especially with Middle Pleistocene Portuguese sites (mainly open air), where the most exploited raw material are quartzite pebbles, seems of outmost importance for future research (Marks 2002; Oosterbeek et al. 2010; Santonja 2016; Santonja \& Villa 2006; Santonja \& Pérez-Gonzalez 2010).

\section{Acknowledgments}

We are thankful to Judith Roberts for the English revision of the text.

\section{References}

Chambers, J.C. 2003, Like a rolling stone? The identification of fluvial transportation damage signatures on secondary context bifaces. Lithics, 24: 66-77.

Cura, S., \& Grimaldi, S. 2009, The intensive quartzite exploitation in Midlle Tagus Valley Pleistocene open air sites - the example of Ribeira da Ponte da Pedra. In: Technological Analysis on Quartzite Exploitation, Proceedings of the XV World Congress IUPPS, Vol. 10 (Grimaldi S., Cura S., Eds.), BAR International Series Vol. 2657, Archeopress, Oxford: p. 49-56.

Cura, S. 2014, Tecnologia Lítica e comportamento humano no Pleistocénico Médio final do Alto Ribatejo: estudo da indústria lítica da Ribeira da Ponte da Pedra. Ph.D. thesis. University of Trás-os-Montes e Alto Douro, Vila Real, 2 Vols, 431 p. (in Portuguese) ("Lithic Technology and Human Behaviour in the final Middle Pleistocene of High Ribatejo: study of the lithic industry of Ribeira da Porte da Pedra")

Cura, S., Cura, P., Grimaldi, S., \& Cristiani, E. 2014, Experimentation and morphotechnical analyses of the Middle Pleistocene lithic assemblage of Ribeira da Ponte da Pedra Site (Central Portugal). In: Technology and Experimentation in Archaeology, Proceedings of the XVI Word Congress of IUPPS, Vol. 10 (Cura, S., Cerezer, J., Gurova, M., 
Santander, B., Oosterbeek, L., \& Cristovão, J., Eds.), BAR International Series Vol. 2657, Archeopress, Oxford: p. 5-16.

Cristiani, E., Cura, S., Grimaldi, S., Gomes, J., Oosterbeek, L., \& Rosina, P. 2010, Functional analysis and experimental archaeology: the Middle Pleistocene site of Ribeira da Atalaia, (Central Portugal). In: Proceedings of the workshop on "Recent Functional Studies on Non-Flint Stone Tools, Methodological Improvements and Archaeological Inferences" (Lisbon 2008) (Araujo Igreja, M., \& Clemente Conte, I., Eds.). Padrão dos Descobrimentos, Lisbon. [CD-ROM] ISBN 978-989-20-1803-4.

Colonge, D., \& Mourre, V., 2009, Quartzite et quartzites, aspects pétrographiques, économiques et technologiques des matériaux majoritaires du Paléolithique ancien et moyen du Sud-Ouest de la France. In: Technological analysis on quartzite exploitation, Proceedings of the IUPPS XVI World Congress, Vol. 10 (Grimaldi, S., \& Cura, S., Eds.), BAR International Series Vol. 2657, Archeopress, Oxford: p. 3-12. (in French) ("Quartzite and quartzite petrographic features, economic and technologic of the main materials of Lower and Middle Palaeolithic of south-west of France")

Cunha, P.P., Martins, A.A., Huot, S., Murray, A., \& Raposo, L. 2008, Dating the Tejo River lower terraces in the Ródão area (Portugal) to assess the role of tectonics and uplift. Geomorphology, 102: 43-54. doi:10.1016/j.geomorph.2007.05.019

Cunha-Ribeiro, J.P. 1999, O Acheulense no Centro de Portugal: o Vale do Lis. Contribuição para uma abordagem das suas indústrias líticas e problemática do contexto cronoestratigráfico. Ph.D. thesis, University of Lisbon, Lisbon, 3 Vols., 692 p. (in Portuguese) ("The Acheulean of central Portugal: the Lis valley. Contribution for an approach to its lithic industries and the problematic of the chrono-stratigraphic context")

Di Modica, K., \& Bonjean, D. 2009, The exploitation of quartzite in Layer 5 (Mousterian) of Scladina Cave (Wallonia, Belgium): Flexibility and dynamics of concepts of debitage in the Middle Palaeolithic. In: Technological Analysis on Quartzite Exploitation, Proceedings of the XVI World Congress of IUPPS, Vol. 10 (Grimaldi S., \& Cura S., Eds), BAR International Series Vol. 2657, Archeopress, Oxford: p. 33-41.

Dias M.I, Prudêncio, M.I., Franco, D., Cura, S., Grimaldi, S., Oosterbeek, L., \& Rosina, P. 2010, Luminescence dating of a fluvial deposit sequence: Ribeira da Ponte da Pedra Middle Tagus Valley, Portugal. In: Archaeometry, Proceedings of the XV World Congress (Grimaldi S., \& Cura, S., Eds.), BAR International Series Vol. 2045, Archaeopress, Oxford: p. 103-113.

Geneste, J.M. 1991, Systèmes techniques de production lithique: variatons technoécnomiques dans les processus de réalisation des outillages paléolithiques. Techniques et culture, 17-18: 1-35. (in French) ("Technical systems of lithic production: technoeconomic variations in the process of realization of Palaeolithic tools") doi:10.4000/tc.683

Grupo para o Estudio do Paleolitico Portugues (GEPP) 1977, O estudo do paleolítico da área do Ródão. O Arqueólogo Português, $3^{a}$ série, 7-9: 31-47. (in Portuguese) (“The study of the Palaeolithic in the region of Rodão")

Hosfield, R.T., \& Chambers, J.C. 2002, Processes and Experiences - Experimental Archaeology on a River Floodplain. In: River Systems and Environmental Change in Wales: Field Guide, (Macklin, M.G., Brewer, P.A., \& Coulthard, T.J., Eds.), British Geomorphological Research Group, Aberystwyth: p. 32-39. 
Hofman, D.L., Pike, A. W. G, Wainer, K., \& Zilhão, J. 2013, New U-series results for the speleogenesis and the Palaeolithic archaeology of the Almonda karstic system (Torres Novas, Portugal). Quaternary International, 294: 168-182. doi:10.1016/j.quaint.2012.05.027

Marks, A.E., Monigal, K., \& Chabai, V. 1999, Report on the initial excavations of Brecha das Lascas and Galeria Pesada (Almonda, Portuguese Estremadura). Journal of Iberian Archaeology, 1: 237-250.

Marks, A.E., Brugal, J.Ph., Chabai, V.P., Monigal, K., Goldeberg, P., Hockett, B., Peman, E., Elorza, M., \& Mallol, C. 2002a, Le gisement Pleistocene moyen de Galeria Pesada, (Estrémadure, Portugal). Premiers résultats. Paléo, 14: 77-100. (in French) ("The Middle Pleistocene of Galeria Pesada (Extremadura, Portugal). First results")

Marks, A.E., Monigal, K., Chabai, V.P., Brugal, J.Ph., Goldeberg, P., Hockett, B., Peman, E., Elorza, M., \& Mallol, C. 2002b, Excavations at the Middle Pleistocene Cave Site of Galeria Pesada, Portuguese Estremadura: 1997-1999. O Arqueólogo Português, Série IV, 20: 7-38.

Marks, A.E. 2005, Micoquian Elements in the Portuguese Middle Pleistocene Assemblages from the Galeria Pesada. In: O Paleolítico: Actas do IV Congresso de Arqueologia Peninsular, (Ferreira Bicho, N., Ed.), Centro de Estudos de Património, Universidade do Algarve, Algarve: p. 195-200.

Martins, A.A., Cunha, P.P., Huot, S., Murray, A., \& Buylaert, J. 2009, Geomorphological correlation of the tectonically displaced Tejo river terraces (Gavião-Chamusca area, Portugal) supported by luminescence dating. Quaternary International, 199: 75-91. doi:10.1016/j.quaint.2009.01.009

Martins, A.A., Cunha, P.P., Rosina, P., Oosterbeek, L., Cura, S., Grimaldi, S., Gomes, J., Buylaert, J.P., Murray, A.S., \& Matos, J. 2010, Geoarcheology of Pleistocene open-air sites in the Vila Nova da Barquinha - Santa Cita area (lower Tejo river basin, central Portugal). Proceedings of the Geologists Association, 121: 128-140. doi:10.1016/j.pgeola.2010.01.005

Meireles, J., \& Cunha-ribeiro, J.P. 1992, Matérias-primas e indústrias líticas do Paleolítico Inferior português: representatividade e significado. Cadernos de Arqueologia, 2: 31-41. (in Portuguese) ("Raw materials and lithic industries of the Lower Palaeolithic in Portugal: representation and meaning")

Meireles, J. 1992, As indústrias líticas do litoral minhoto. Contexto cronoestratigráfico e paleoambiental. Cadernos de Arqueologia, Monografias 7. Universidade do Minho, Braga, 763 p. (in Portuguese) ("The lithic industries of the Minho litoral. Chronostratigraphic and paleo-environmental context")

Moloney, N., Raposo, L., \& Santonja, M. (Eds.) 1996, Non-flint Stone Tools and the Palaeolithic Occupation of the Iberian Peninsula, British Archaeological Reports International Series Vol. 649, Archeopress, Oxford, 191 p.

Mozzi, P. 1998, Evoluzione Geomorfologica della bassa valle del fiume Nabão. Arkeos, 4: 37-58. (in Italian) ("Geomorphologic evolution of the lower basin valley of the Nabão River")

Mozzi, P., Azevedo, T., Nunes, E., \& Raposo, L. 2000, Middle terrace deposits of the Tagusriver in Alpiarça, Portugal, in relation to early human occupation. Quaternary Research, 54: 359-371. doi:10.1006/qres.2000.2154 
Moncel, M-H., Lombrera Hermida, A., \& Deniaux 2009, Quartz et Quartzite dans les niveauxd'occupation OIS7 et 5 du site de Payre (Sud-est, France): fonction spécifique et complémentaire? In: Technological Analysis on Quartzite Exploitation, Proceedings of the XVI Word Congress of IUPPS, Vol. 10 (Grimaldi S., \& Cura S., Eds.), BAR International Series Vol. 2657, Archeopress, Oxford: p. 13-23.

Osterbeek, L., Grimaldi, S., Rosina, P., Cura, S., Gomes, J., Cunha, P., \& Martins, A. 2010, The earliest Pleistocene archaeological sites in western Iberia: Present evidence and research prospects. Quaternary International, 122(3): 399-407. doi:10.1016/j.quaint.2010.01.024

Pereira, T., Cascalheira, J., Marreiros, J., Almeida, F., \& Bicho, N. 2012, Variación en la explotación de la cuarcita durante el Paleolítico Superior en el Suroeste de la Península Ibérica. Trabajos de Prehistoria, 69(2): 232-256. doi: 10.3989/tp.2012.12090 (in Spanish) ("Variation of quartzite exploitation during the Upper Palaeolithic in the Southwest of Iberian Peninsula").

Raposo, L., Carreira, J.R., \& Salvador, M. 1985, A estação Acheulense final de Milharós, Vale do Forno, Alpiarça. In: I Reunião do Quaternário Ibérico (Proceedings), Vol. 2. Grupo de Trabalho Português para o Estudo do Quaternário, and Asociación Española para el Estudio del Cuaternario (GTPEQ/AEEC), Lisbon: p. 79-90. (in Portuguese) ("The final Acheulean site of Milharós, Vale do Forno, Alpiarça")

Raposo, L., 1987, Os mais antigos vestígios de ocupação humana paleolítica na região de Ródão. Da Pré -História a História, homenagem a O. Veiga Ferreir, Editorial Delta, Lisboa: p. 153-178. (in Portuguese) ("The most ancient remains of human occupation in the region of Rodão")

Raposo, L., Salvador, M., \& Pereira, J.P. 1993, O Acheulense no Vale do Tejo, em território português. Arqueologia \& História, 10(3): 3-29. (in Portuguese) ("The Acheulean of the Tagus valley in Portuguese territory”)

Raposo, L. 2000, The middle-upper Palaeolithic transition in Portugal. In: Neanderthals on the Edge: $150^{\text {th }}$ Anniversary Conference of the Forbes' Quarry Discovery, Gibraltar (Stringer, C., Barton, R.N.E., \& Finlayson, C., Eds.), Oxbow Books, Oxford: p. 95-109.

Rodet, M., Prous, A., Machado, J., \& Bassi, L.F. 2014, Les industries des sites du haut rio São Francisco: outilllage "simple", ou "complexe"? le Cimetiere de Buritizeiro et l'abri Bibocas de Jequitai. In Technology and Experimentation in Archaeology, Proceedings of the XVI Word Congress of IUPPS, Vol. 10 (Cura, S., Cerezer, J., Gurova, M., Santander, B., Oosterbeek, L., \& Cristovão, J., Eds.), BAR International Series Vol. 2657, Archeopress, Oxford: p. 33-39. (in French) ("The industries of the sites of the high Sa Francisco River: simple or complex tools? The grave of Buritizeiro and the shelter of Bicocas of Jequetai").

Rosina, P. 2002, Stratigraphie et géomorphologie des terrasses fluviatiles de la moyenne Vallée du Tage (Haut Ribatejo, Portugal). In: Territórios, mobilidade e povoamento no Alto-Ribatejo.IV: Contextos macrolíticos (Cruz, A.R., \& Oosterbeek, L., Eds.), Arkeos Vol. 4, (Centro Europeu de Investigação da Pre-Historia do Alto Ribatejo) CEIPHAR, Tomar: p. 11-52. (in French) ("Stratigraphy and geomorphology of the middle Tagus valley fluvial terraces")

Rosina, P. 2004, I depositi quaternari nella Media Valle del Tago (Alto Ribatejo, Portogallocentrale) e le industrielitiche associate. Ph.D. thesis. University of Ferrara, 
Ferrara, 204 p. (in Italian) ("The Quaternary deposits of the middle Tagus valley (High

Ribatejo, Central Portugal) and the associated lithic industries")

Rosina, P., \& Cura, S. 2010, Interpretation of lithic remains in fluvial terrace contexts: an example from Central Portugal. Annales d'Université Valahia Târgoviste. Section d'Archéologie et d'Histoire, 12(1): p. 7-24.

Rosina, P., Cura, S., Grimaldi, S., \& Gomes, J. 2011, The Middle-Upper Pleistocene open air site of Ribeira Ponte da Pedra (Middle Tagus Basin, Central Portugal). In: Proceedings of the XV UISPP World Congress (Oosterbeek, L., \& Fidalgo, C., Eds.), BAR International Series Vol, 47, Archeopress, Oxford: p. 169-180.

Rosina, P., Voinchet,P., Bahain, J.J., Cristovão, J., \& Falguéres, C. 2014, Dating the onset of Lower Tagus River terrace formation using electron spin resonance. Journal of Quaternary Science, 29(2): 153-162. doi:10.1002/jqs.2689

Santonja, M., \& Villa, P. 2006, The Acheulean of Western Europe. In: Axe Age. Acheulean Tool making from Quarry to Discard (Goren-Inbar, N., \& Sharon, G., Eds.), Equinox, London: p. 429-478.

Santonja, M., \& Pèrez-Gonzalez, A. 2010, Mid-Pleistocene Acheulean industrial complex in the Iberian Peninsula. Quaternary International, 223-224:154-161. doi:10.1016/j.quaint.2010.02.010

Santonja, M., Pérez-González, A., Panera, J., Rubio-Jara, S., \& Méndez-Quintas, E., 2016, The coexistence of Acheulean and Ancient Middle Palaeolithic techno-complexes in the Middle Pleistocene of the Iberian Peninsula. Quaternary International, 411: 367-377. doi:10.1016/j.quaint.2015.04.056

Sternke, F., Eigeland, L., \& Costa, L.J. (Eds.) 2009, Non-Flint Raw Material Use in Prehistory. Old Prejudices and New Direction, Proceedings of the C 77 XV UISPP World Congress. Archaeopress, Oxford, 248 p.

Trinkaus, E., Marks, A.E., Brugal, J.P., Bailey, S.E., Rink, W.J., \& Richter, D., 2003, Later Middle Pleistocene human remains from the Almonda Karst system, Torres Novas, Portugal. Journal of Human Evolution, 45: 219-226. doi:10.1016/j.jhevol.2003.07.001

Tuffreau, A., Goval, E., Lefevre, B., Boroneant, V., Boroneant,A., Dobos, A., \& Popescu, G. 2009, L'utilisation du quartzite dans l'industrie moustérienne de Zabrani (Banat, Roumanie). In: Technological analysis on quartzite exploitation, Proceedings of the XVI Word Congress of IUPPS (Grimaldi, S., \& Cura, S., Eds.), BAR International Series Vol. 2657, Archeopress, Oxford: p. 25-32. (in French) ("The utilization of quartzite in the Mousterian industry of Zabrani (Banat, Romenia)")

Utrilla, P., \& Mazo, C. 1996, Non-flint raw materials in La Rioja: a tentative interpretation. In: Non-flint Stone Tools and the Palaeolithic Occupation of the Iberian Peninsula (Moloney, N., Raposo, L., \& Santonja, M., Eds.), BAR International Series Vol. 649, Archeopress, Oxford: p. 63-80. 